\section{Cytotoxicity of Root Canal Sealers on Endothelial Cell Cultures}

Vagner José Medeiros Martins', Renata Ximenes Lins², Teresa Cristina Ávila Berlinck², Rivail Antônio Sérgio Fidel ${ }^{2}$

This study evaluated, in vitro, the cytotoxicity of six root canal sealers after 12,24 and $72 \mathrm{~h}$ of contact time, using an endothelial ECV-304 cell line. The MTT assay was used for analysis of cell viability. Twelve specimens of each sealer were prepared and randomly assigned to 6 groups according to the commercial brands ( $n=4 /$ time). A control group was also formed, which was not subjected to the contact with sealers. To assess the effects of sealers on endothelial cells, the specimens were placed in culture plate wells and incubated at $37^{\circ} \mathrm{C}$ with $5 \% \mathrm{CO}_{2}$ and $100 \%$ humidity. MTT assays were performed in quadruplicate after 12, 24 and $72 \mathrm{~h}$ of contact of the sealer specimens with monolayers. Statistical analysis was performed by two-way ANOVA with Bonferroni post-hoc test at a significance level of $5 \%$. Analysis of absorbance in the experimental groups showed that GuttaFlow presented the lowest cytotoxicity, with a mean absorbance of 0.048 , followed by Pulp Canal Sealer (0.038), Sealer 26 (0.038), Endo Densell (0.036) and Pulp Fill (0.035). The control group had a mean absorbance of 0.098. Based on the results, Endofill and GuttaFlow were the most and the least cytotoxic sealers, respectively.
'UFJF - Federal University of Juiz de Fora, Juiz de Fora, MG, Brazil 2UERJ - State University of Rio de Janeiro, Rio de Janeiro, RJ, Brazil

Correspondence: Vagner José Medeiros Martins, Rua José Lourenço Kelmer, S/N, 36036-900 Juiz de Fora, MG, Brasil. Tel: +55-32-2102-3857. e-mail: vagner.jose@ufjf.edu.br
Key Words: cell cytotoxicity, root canal sealers, cell culture, culture media, endothelial cells.

\section{Introdution}

Cytotoxicity is a complex in vivo phenomenon that can trigger a broad spectrum of effects from a simple cell death to metabolic aberrations with functional or routespecific changes $(1,2)$.

Among the various recommended methodologies for assessing biocompatibility and cytotoxicity of dental materials at different levels of research, in vitro cell culture tests are part of the initial protocols most widely used by some researchers (3-7).

The first in vitro studies using cell cultures to assess the cytotoxicity of dental materials were carried out in the late 1960's (8). Cell culture refers to culture derived from scattered cells removed from the original tissue, a primary culture, or a cell line that had already been established in culture by enzymatic, mechanical or chemical disruption (9).

Permanent cell lines or primary cultures (e.g., gingiva, mucosa and pulp fibroblasts) can be used, but primary cultures are known to reflect more accurately in vivo situations despite being difficult to cultivate (10). ECV304 endothelial cells are obtained from the human umbilical cord vein. This line is characterized by a monolayered growth pattern, high proliferative potential, with no growth factor-specific requirement (11).

The MTT solution is a tetrazolium salt reduced to formazan by mitochondrial enzymes of viable cells proportionally to the dehydrogenase activity, and is defined as a 3-(4.5-dimethylthiazol-2-yl)-2.5-diphenyl-tetrazolium bromide colorimetric assay. This method is applied to assess cell survival and proliferation and detects the signal produced by the activation of living cells. This is a low-cost procedure that yields results within $48 \mathrm{~h}$ (12).

Root canal sealers have a major role in avoiding apical percolation by sealing branches and providing improved filling adjustment to the irregularities found on the dentin/ filling material interface. These materials must fill the dentinal tubules, closely adhere to the organic and inorganic phases of the dentin, destroy or neutralize microorganisms and their byproducts, induce new cementum formation and strengthen the root canal system. From this perspective, all sealers in use can be considered inappropriate (13).

In this study, the MTT assay was used to assess the in vitro cytotoxicity of Densell Endo, Pulp-Fill, Endofill, Sealer 26, Pulp Canal Sealer and GuttaFlow root canal sealers after 12,24 , and $72 \mathrm{~h}$ of contact with an endothelial ECV-304 cell line from the human umbilical cord veins.

\section{Material and Methods}

ECV-304 endothelial cells were obtained from the Microbiology and Immunology (DIMI) courses from the Medical Sciences School at the Biomedical Center of the State University of Rio de Janeiro, RJ, Brazil.

In compliance with ISO 10993-5:2009 standard "Biological evaluation of medical devices. Part 5. Test for in vitro cytotoxicity", cells were kept frozen at $-70^{\circ} \mathrm{C}$ in a F12 medium supplemented with 5\% DMSO and 95\% fetal bovine serum (Gibco, Grand Island, NY, USA). For defrosting, cells were rapidly shaken in hot water bath at $37^{\circ} \mathrm{C}$, while still in the stock medium (5\% DMSO and 95\% fetal bovine serum). The tubes were then washed with $70 \%$ ethanol and 
placed in a laminar flow to ensure complete drying before being effectively opened. For cell culturing, the contents in the cryogenic tube were transferred to $25-\mathrm{cm}^{3}$ sterile bottles. Cell suspension was kept in an incubator (Shel Lab Laboratory; Sheldon Manufacturing, Cornelius, OR, USA) with temperature and pressure control in a humid setting at $37^{\circ} \mathrm{C}$ and $5 \% \mathrm{CO}_{2}$.

The first medium replacement was established at $24 \mathrm{~h}$ in order to remove the remaining DMSO. Cell passaging was performed after 48 -h periods until confluent cultures could be obtained. The distribution of $100 \mu \mathrm{L}$ of the medium containing cells in a concentration of $1.5 \times 10^{6}$ cells $/ \mathrm{mL}$ per micro-plate well was done in order to culture cells from 96 wells, incubated at $37^{\circ} \mathrm{C}$ in the presence of $5 \% \mathrm{CO}_{2}$. After distribution, cells were kept at $37^{\circ} \mathrm{C}$ with $5 \% \mathrm{CO}_{2}$ for $48 \mathrm{~h}$ for experimentation.

In order to assess cell viability, an MTT cytotoxicity assay consisting of tetrazolium salt reduced to formazan by mitochondrial enzymes of viable cells was used proportionally to its dehydrogenase activity and defined as a 3-(4.5-dimethylthiazol-2-yl)-2.5-diphenyl-tetrazolium bromide colorimetric assay (11).

Twelve test specimens were prepared for each sealer ( $3 \mathrm{~mm}$ diameter and $1 \mathrm{~mm}$ high) using six stainless steel devices (mold + extractor) specifically designed for this study. The devices were properly sterilized and filled with freshly mixed sealer according to each manufacturer's instructions.

After the setting time required for each sealer, the specimens were allocated to 6 experimental groups according to the commercial brands, and one control group that was not subjected to the contact with sealers. Immediately after fabrication, the test specimens were allocated onto Petri dishes, which were placed in a microwave oven for two 5-min cycles at maximum output for the sterilization process. Following this, the test specimens were exposed to ultraviolet light for a period of approximately $30 \mathrm{~min}$ for surface disinfection.

In order to assess the effect of sealers on the ECV-304 endothelial cells, test specimens were placed in culture plate wells containing $25 \mathrm{mg} / \mathrm{mL}$ suspension in a culture medium and incubated at $37^{\circ} \mathrm{C}$ with $5 \% \mathrm{CO}_{2}$ and $100 \%$ humidity. MTT reduction tests were done in quadruplicate at 12,24 , and $72 \mathrm{~h}$ using 96 -well cell culture microplates. Samples were sequentially incubated 72,24 , and $12 \mathrm{~h}$ before analysis. This procedure was chosen so that all the samples could be analyzed at the same time.

For the cell viability test, the specimens were removed after an incubation period of 12,24 , and $72 \mathrm{~h}$, and the cultures were washed with phosphate buffer saline (PBS) and incubated in a $1 \mathrm{mg} / \mathrm{mL} M T$ solution in a DMEM medium for $1 \mathrm{~h}$ at $37^{\circ} \mathrm{C}$ with $5 \% \mathrm{CO}_{2}$. In each well, $200 \mu \mathrm{L}$ isopropyl alcohol (Merck \& Co. Inc, Whitehouse Station, NJ, USA) was added for formazan solubilization, and two aliquots of $100 \mu \mathrm{L}$ alcohol containing solubilized formazan were removed from each well and transferred onto another microplate also containing 96 wells, and thus the number of samples doubled. The microplate was transferred to an ELISA spectrophotometer (Biorad Laboratories, Richmond, CA, USA) where the absorbance values were determined at $570 \mathrm{~nm}\left(\mathrm{~A}_{570}\right)$.

Two-way ANOVA test was used in combination with Bonferroni's post-hoc test to identify differences among groups and times, with a significance level of $5 \%$.

\section{Results}

At the 12-h analysis the GuttaFlow had the least cytotoxicity with a mean absorbance of 0.055 , followed by Sealer 26 (0.038). Pulp Canal Sealer and Densell Endo showed the same mean absorbance (0.031). Pulp Fill and Endofill showed the greatest cytotoxicity (mean absorbance 0.024 and 0.021 , respectively) among all sealers. The control group had a mean absorbance of 0.158 (Fig. 1A).

At the 24-h analysis, GuttaFlow and Sealer 26 once again had the greatest mean absorbance $(0.041$ and 0.037 , respectively) proving to be the least cytotoxic, followed by the Pulp Canal Sealer which had a mean absorbance of 0.035. Densell Endo and Pulp Fill, however, had similar cytotoxicity with mean absorbance of 0.033 and 0.032 , respectively. The Endofill once again proved to be the most cytotoxic (0.026). The control group had a mean absorbance of 0.086 (Fig. 1B).

At $72 \mathrm{~h}$ (Fig. C), Pulp Canal Sealer had the least cytotoxicity with a mean absorbance of 0.049 , followed by the GuttaFlow and Pulp Fill, both with a mean absorbance of 0.048. Densell Endo, Sealer 26, and Endofill had mean absorbance of $0.044,0.040$ and 0.036 , respectively. Most important, the control group's mean absorbance $(0.050)$ was close to those exhibited by the experimental groups.

As shown in Figure 2, the control group differed significantly from all groups at all times. The results showed the greatest cytotoxicity for Endofill while GuttaFlow had the lowest absorbance values. When compared over time, the experimental groups were found to behave differently in addition to having different absorbance values. It is worth noting that all groups tended to reach the same levels within $72 \mathrm{~h}$ due to the fact that they were near confluence.

When overall mean absorbance values for all groups were analyzed (Fig. 3), GuttaFlow was found to have the lowest cytotoxicity level, with a mean absorbance of 0.048 . Pulp Canal Sealer and Sealer 26 were next with equal mean absorbance values of 0.038 , followed by Densell Endo and Pulp Fill, with 0.036 and 0.035 , respectively. The sealer with the lowest mean absorbance, and therefore the most 
cytotoxic in the study, was Endofill (0.027). The control group had a mean absorbance of 0.098 .

\section{Discussion}

Assessing cytotoxicity is important because it allows understanding the biological mechanism that produces the cytotoxic effect and the mechanism of action of different materials during material/tissue interaction. However, it is recognized that the test has its limitations. The use of cell cultures in monolayers is not physiological, and does not reproduce the in vivo tissue architecture in which underlying cells could repair surface aggression. The presence of an in vitro cytotoxic effect does not guarantee that the material is toxic when applied in vivo. On the other hand, absence of a cytotoxic effect ensures good clinical response.
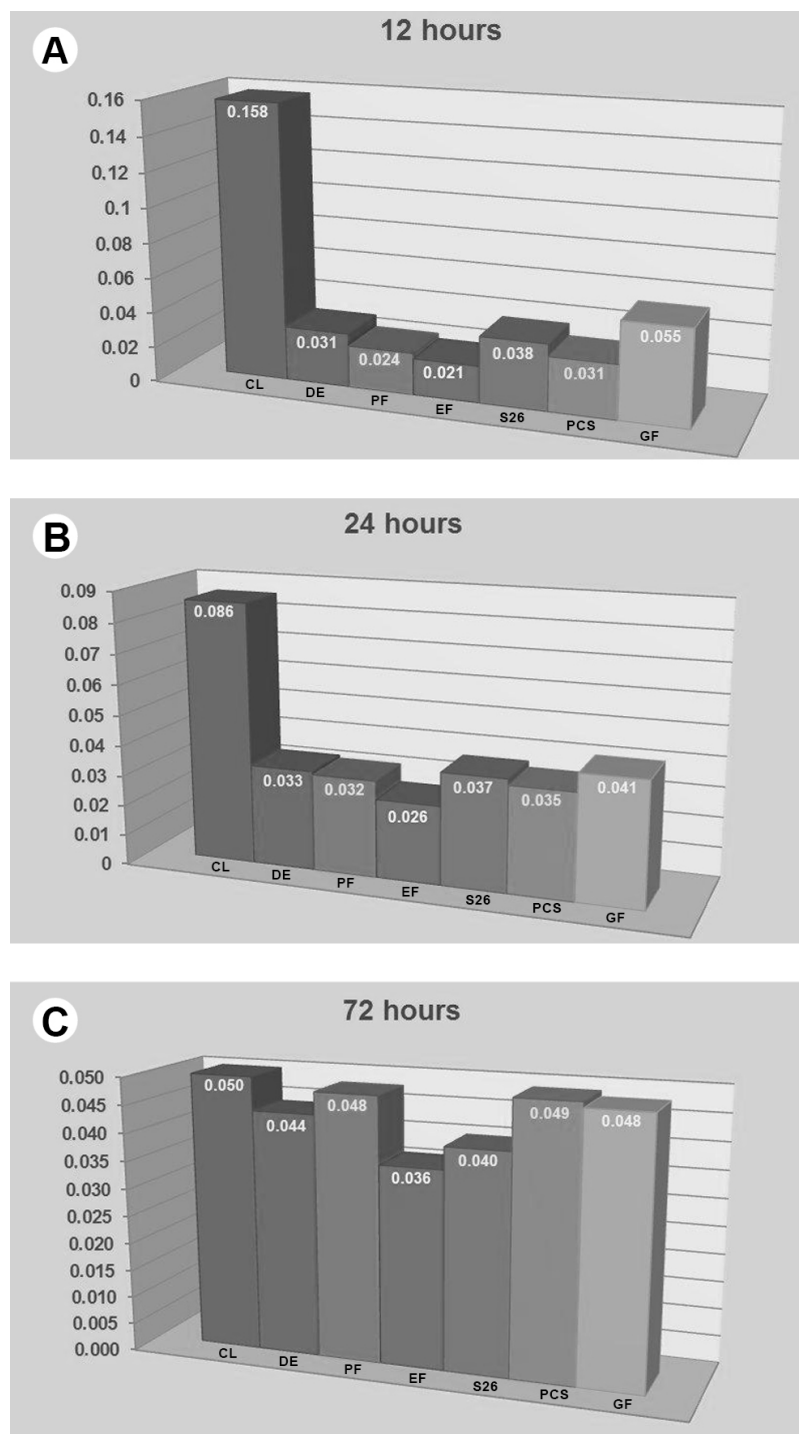

Figure 1. Mean absorbance values at $12 \mathrm{~h}(\mathrm{~A}), 24 \mathrm{~h}$ (B) and 72 h (C). CL: Control. DE: Densell. PF: Pulp Fill Endo. EF: Endofill. S26: Sealer 26. PCS: Pulp Canal Sealer. GF: GuttaFlow.
It should be noted that NCTC clone 929 is still used in cytotoxicity studies. Some authors (9) have described cell culture as a culture derived from scattered cells removed from the original tissue, a primary culture, or a cell line that had already been established in culture by enzymatic, mechanical or chemical disruption.

ECs are also an important source of pro-inflammatory mediators and vascular tone modulators, besides expressing adherence molecules and secreting/activating chemoattraction factors that control leukocyte draft. EC culture can demonstrate its specific capacity to produce endothelin and NO (14).

ECV-304 endothelial cells are obtained from the human umbilical cord vein, spontaneously immortalized, and are characterized by a monolayered growth pattern, high proliferative potential, with no growth factor-specific requirement (11). For this study, ECV-304 cells were used and cultured until confluent cultures at $37^{\circ} \mathrm{C}$ could be obtained.

Subculturing also involves removing the culture medium and dissociating monolayer cells with trypsin and/

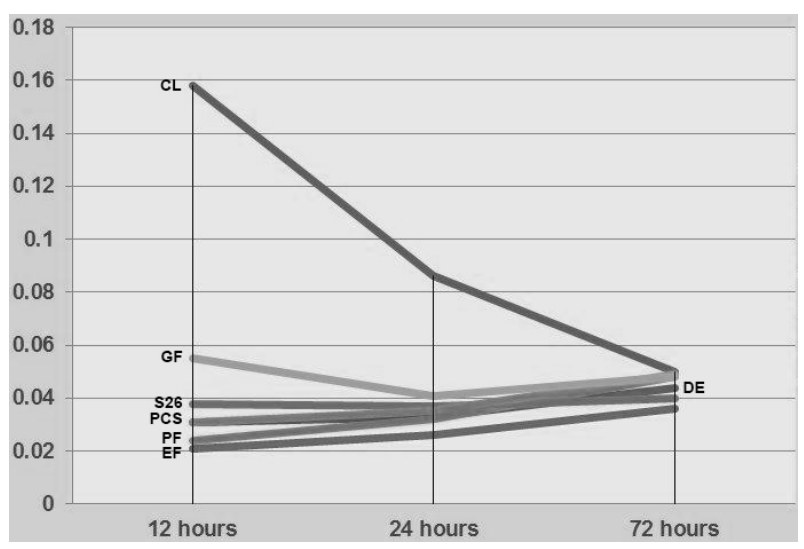

Figure 2. Mean absorbance values of the cements at the different time points. CL: Control. DE: Densell. PF: Pulp Fill Endo. EF: Endofill. S26: Sealer 26. PCS: Pulp Canal Sealer. GF: GuttaFlow.

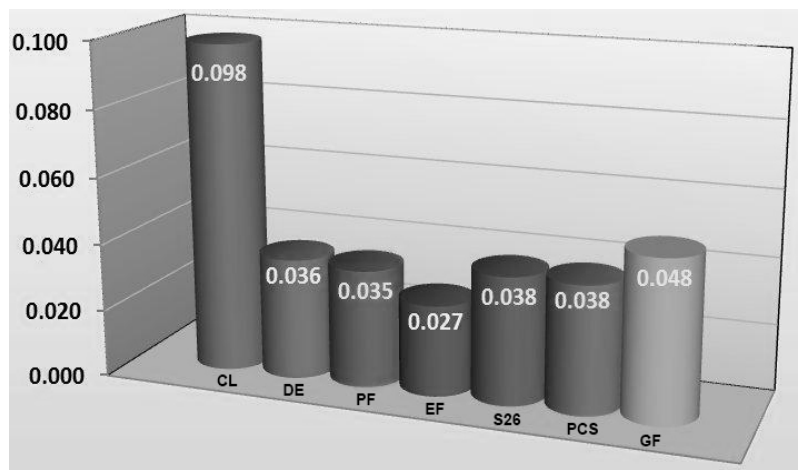

Figure 3. Overall mean absorbance values of the cements regardless of the evaluation time. CL: Control. DE: Densell. PF: Pulp Fill Endo. EF: Endofill. S26: Sealer 26. PCS: Pulp Canal Sealer. GF: GuttaFlow. 
or EDTA. These substances were also used in this study (10 $\mathrm{mL}$ solution containing 0.1\% trypsin and 0.01\% EDTA at $37^{\circ} \mathrm{C}$ ) for treating cells removed from cryogenic tubes and transferred to $25 \mathrm{~cm}^{3}$ sterile bottles (13).

As reported by some authors (15), changes in culture and subculture media have varied intervals according to the used cell line. Therefore, the line should be properly considered when selecting a subculturing protocol, and choose the protocol that causes the least damage to the cells, as advocated by other authors. For this study, subsequent media changes were done after $48 \mathrm{~h}$ until a confluent culture could be obtained.

Cell culture techniques are widely used because they are cost-effective, relatively easy to maintain and require little physical space. Additionally, they can be used to prepare antigens, monoclonal antibodies and vaccines, as well as to isolate microorganisms, especially viruses, and to assess cytotoxicity in a wide range of products.

Cytotoxicity is a complex phenomenon that can result in a broad spectrum of effects from a simple cell death to metabolic aberrations with functional or route-specific changes $(2,9)$. The definition of cytotoxicity in a trial may vary depending on the nature of the trial. Some experiments cytotoxicity tests and selects the most suitable method is the ISO 10993-5 standard, as established in 1992 (9).

Benefits from in vitro toxicity tests when compared with animal experiments and clinical studies in humans include control of the experimental conditions, low cost, fast performance and absence of ethical issues $(9,11)$.

In vitro tests can be done by using permanent cell lines or primary cultures (e.g., gingiva, mucosa, and pulp fibroblasts); however, primary cultures are known to reflect in vivo situations more precisely despite being difficult to culture (10). The first in vitro study using cell cultures to assess dental material cytotoxicity were carried out by Kawahara (8) and, according to most authors $(1,4-7,9,10)$, in vitro cell culture tests are part of the most commonly used protocols within the recommended methodologies for assessing dental material biocompatibility and cytotoxicity at different levels of research.

This type of test is beneficial because it can be experimentally controlled and allows for methodological standardization, in addition to being fast, relatively inexpensive, simple and able to replace experiments on animals and human patients. Because they are carried out away from any contact with the organism, many complex interactions that mask biological response in the body are not present $(1,9)$. In view of that, in vitro experiments were chosen for this study because, as pointed out by most authors, they are important in producing knowledge as well as enabling modifications in the substance structure before being used on animal and/or human models.

The latter categorization was chosen for this experiment where the test specimen was placed over confluent cells, as determined by some authors (16), with special emphasis on the changes that the material can cause to cells during the experiment. Other authors (17) have pointed out that direct contact of test specimens obtained from different materials may inhibit cell growth due to physical contact, not from the toxic substances that are released. For some authors (8), there is no standard time for cytotoxicity tests, since each material is cytotoxic at different levels. For this investigation, analyses were done by direct contact with non-water-soluble materials at 12,24 , and $72 \mathrm{~h}$.

In vitro tests assess material properties directly in cell cultures that react to the effects of the products being analyzed. An example is the MTT assay. In this assay, the yellow MTT salt, which has a ring-shaped molecular structure, is absorbed by cells and cleaved by an enzyme inside the mitochondria, giving origin to a product named formazan in the form of purple-colored non-soluble crystals $(12,18,19)$. To achieve this result, the identification of the color intensity of the solution is done by an ELISA spectrophotometer, with a high accurate reading in cytotoxicity studies (18). As previously outlined (12), this method assesses cell survival and proliferation, and detects the signal produced by the activation of living cells. The product that builds up inside the cell is extracted by adding an appropriate solvent and observing it with a digital spectrophotometer.

Placing material to be tested either directly or indirectly in contact with a cell culture is defined as a cytotoxicity test. Additionally, cell changes brought on by the material must be observed by taking into account the appropriate time. It is the understanding of the authors (16) that there are several methods for observing these changes like, for example, the incorporation of vital dyes or the inhibition of cell colonies.

An advantage of the MTT assay is that it can identify changes in metabolism and cell function from contact within cells and materials, even in the absence of dead cells (20). Additionally, it is a low-cost procedure that yields results within $48 \mathrm{~h}(12,13,18,19)$, and is therefore the most commonly used procedure for determining the cytotoxicity of different types of materials (20). Due to these characteristics and the endorsement by some authors $(13,15,21-25)$, this assay was used in this study for assessing the cytotoxicity of all the six endodontic sealers.

For this study, test specimens were prepared after 
handling sealers according to each manufacturer's instructions $(11,14,22)$ and using devices (mold + extractor) specifically designed for the study and properly sterilized before use. For correct sterilization, test specimens were placed on a Petri plate and put in a microwave oven for two 5 -min cycles at maximum output. For surface disinfection, test specimens were exposed to ultraviolet light $(14,25)$, for approximately $30 \mathrm{~h}$. However, some authors (14) used a 2-h period whereas others (25) used a 24-h period.

This type of incubation used in the present study to assess the effect of the sealers on ECV-304 cells has been used elsewhere $(13,15,23-25)$. A previous study (13) also used ECV-304 cells that were incubated at $37^{\circ} \mathrm{C}$ in $5 \%$ $\mathrm{CO}_{2}$ and $100 \%$ humidity for 7 days and cultured in an F12 medium supplemented with 10\% fetal bovine serum.

In a previous study (23), confluent cells were enhanced with $0.25 \%$ trypsin and $0.05 \%$ EDTA for $5 \mathrm{~min}$, and aliquots of separated cells were subcultured. After a 24-h incubation period, cytotoxicity was assessed by an MTT assay. In a research by other authors (15), a subculture was conducted with confluent culture cells treated with $0.5 \mathrm{~g} / \mathrm{L} / 0.2 \mathrm{~g} / \mathrm{L}$ EDTA in phosphate buffered saline (PBS). In this research, for ECV-304 cell culturing (ISO 10.993-5), the contents in the cryogenic tube was transferred to $25-\mathrm{cm}^{3}$ sterile bottles,

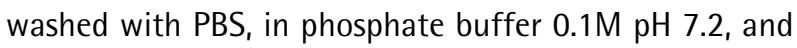
treated with $10 \mathrm{~mL}$ solution containing $0.1 \%$ trypsin and $0.01 \%$ EDTA at $37^{\circ} \mathrm{C}$.

The MTT assay was used to assess cell viability $(12,13,15,18,20,22-25)$. The MTT reduction tests were performed in quadruplicate at 12,24 , and $72 \mathrm{~h}$ using 96-well cell culture microplates. Ninety-six wells were filled in order to have a safety margin, since only 84 wells would be analyzed. This procedure was chosen so that all the samples could be analyzed at the same time. The microplate was transferred to an ELISA spectrophotometer where absorbance values were determined at $570 \mathrm{~nm}\left(A_{570}\right)$.

The biological tests are important considering that materials used in the oral cavity should be nontoxic, nonabsorbable by the circulatory system, and should not cause injuries to the oral tissues. Non-biocompatible materials may prove mutagenic or influence inflammation mediators causing systemic responses, including cytotoxic, teratogenic or carcinogenic effects. These materials must be free of agents that may cause allergic responses to individuals who are sensitive to these substances.

According to the categories in which dental materials are classified, different research protocols should be developed in order to evaluate and determine the biological behavior and possible indications for clinical use. For a dental sealer to be clinically successful, the whole system must be biocompatible. Therefore, tests are recommended to evaluate biocompatibility. They are a preliminary approach to assess a particular dental material and characterize its cytotoxicity profile in a specific biological system.

At the 12-h analysis, Pulp Fill and Endofill showed the highest cytotoxicity. GuttaFlow showed the lowest cytotoxicity, followed by Sealer 26, Pulp Canal Sealer, and Densell Endo. For the 24-h period, GuttaFlow and Sealer 26 continued to show lower cytotoxicity, followed by the Pulp Canal Sealer. However, Densell Endo and Pulp Fill had similar cytotoxicity. Endofill once again was found to be more cytotoxic then the other sealers. After $72 \mathrm{~h}$, Pulp Canal Sealer showed the lowest cytotoxicity, followed by GuttaFlow, Pulp Fill, Densell Endo, and Sealer 26. However, Endofill remained the most cytotoxic.

Considering the mean absorbance values obtained at three time points, Endofill showed the highest and GuttaFlow the lowest cytotoxicity, respectively.

\section{Resumo}

Este estudo avaliou, in vitro, a citotoxicidade de 6 cimentos endodônticos após 12,24 e $72 \mathrm{~h}$ de tempo de contato, utilizando-se uma linhagem de células endoteliais ECV-304. Para a avaliação da viabilidade celular, utilizou-se o teste de citotoxicidade MTT. Para cada cimento foram preparados 12 corpos de prova que foram distribuidos em 6 grupos experimentais de acordo com as marcas comerciais, sendo 4 para cada tempo. Foi criado um grupo controle que não foi submetido à ação de cimento. Para avaliação do efeito dos cimentos sobre as células endoteliais, os corpos de prova foram inseridos nos poços da placa cultura, incubados a $37^{\circ} \mathrm{C}$ em presença de $5 \%$ de $\mathrm{CO}_{2}$ e $100 \%$ de umidade. Os testes MTT foram realizados em quadruplicata, após 12, 24 e $72 \mathrm{~h}$ de contato das amostras com o tapete celular. Foi utilizada a prova two-way Anova com o teste post hoc de Bonferroni com nível de significância de 5\%. Quando analisadas as médias gerais de absorbância dos grupos analisados observou-se que o cimento GuttaFlow se apresentou como o cimento com menor índice de citotoxicidade, apresentando média de absorbência de 0,048. Logo após, apresentando médias de absorbância iguais $(0,038)$ encontraram-se os cimentos Pulp Canal Sealer e Sealer 26; seguidos do Densell Endo e do Pulp Fill, com 0,036 e 0,035, respectivamente. 0 grupo controle apresentou média de absorbância de 0,098 . Portanto, tendo como base os resultados obtidos, pôde-se concluir que o cimento Endofill foi o que apresentou maior citotoxicidade e o cimento GuttaFlow, o menos citotóxico.

\section{References}

1. Freshney RI. Culture of animal cells: a manual of basic technique. $5^{\text {th }}$ ed. New York: Wiley-Liss; 2005.

2. Grimsdottir MR, Henster-Petersen A. Cytotoxicity and antibacterial effects of orthodontic appliances. Scand J Dent Res 1993;101:229-231.

3. Costa CA, Vaerten MA, Edwards CA, Hanks CT. Cytotoxic effects of current dental adhesive systems on immortalized odontoblast cell line MDPC-23. Dent Mater 1999;15:434-441.

4. Geurtsen W, Lehmann F, Spahl W, Leyhausen G. Cytotoxicity of 35 dental resins composite monomers/additives in permanent 3 T3 and three human primary fibroblast cultures. J Biomed Mater Res 1998;5:474-480.

5. Kaga M, Noda M, Ferracane JL, Nakamura W, Oguchi H, Sano H. The in vitro cytotoxicity of eluates from dentin bonding resins and their effects on tyrosine phosphorylation of L929 cells. Dent Mater 2001;17:333-339.

6. MacDougall M, Selden JK, Nydegger JR, Carnes DL. Immortalized odontoblast cell line M06-G3 application for in vitro biocompatibility testing. Am J Dent 1998;11:11-16.

7. Ratanasathien $\mathrm{S}$, Wataha JC, Hanks CT, Dennison JB. Interative effects 
of dentin bonding components on mouse fibroblasts. J Dent Res 1995;9:1602-1606.

8. Kawahara H, Yamagami A, Nakamura M Jr. Biological testing of dental materials by means of tissue culture. Int Dent J 1968;18:443-446.

9. Wataha JC. Principles of biocompatibility for dental practitioners. J Prosthet Dent 2001;86:203-209.

10. Schmalz G. Use of cell cultures for toxicity testing of dental materials - advantages and limitations. J Dent 1994;22:6-11.

11. Takahashi K, Sawasaki Y, Hata J, Mukai K, Goto T. Spontaneous transformation and immortalization of human endothelial cells. In Vitro Cell Dev Biol 1990;26:265-274.

12. Mosmann T. Rapid colorimetric assay for cellular growth and survival; application to proliferation and cytotoxicity assays. J Immunol Methods 1983;65:55-63.

13. De-Deus G, Ximenes R, Gurgel-Filho ED, Plotkowski MC, CoutinhoFilho T. Cytotoxicity of MTA and Portland cement on human EVC 304 endothelial cells. Int Endod J 2005;38:604-609.

14. Miletić I, Devčić N, Anić I, Borčić J, Karlović Z, Osmak M. The cytotoxicity of RoekoSeal and AH Plus compared during different setting periods. J Endod 2005;31:307-309.

15. Eldeniz AU, Mustafa K, Ørstavik D, Dahl JE. Cytotoxicity of new resin-, calcium hydroxide- and silicone-based root canal sealers on fibroblasts derived from human gingiva and L929 cell lines. Int Endod J 2007;40:329-337.

16. Ciapetti G, Granchi D, Verri E, Savarino L, Cavedagna D, Pizzoferrato A. Application of a combination of a neutral red and amido black staining for rapid, reliable cytotoxicity testing of biomaterials. Biomaterials 1996;17:1259-1264.
17. Tang AT, Li J, Ekstrand J, Liu Y. Cytotoxicity tests of in situ polymerized resins: methodological comparisons and introduction of a tissue culture insert as a testing device. J Biomed Mater Res 1999;45:214-223.

18. Locci P, Marinucci L, Lilli C, Belcastro S, Staffolani N, Bellocchio S, et al.. Biocompatibility of alloys used in Orthodontics evaluated by cell culture test. J Biomed Mater Res 2000;15:561-568.

19. Bouillaguet $\mathrm{S}$, Wataha JC, Lockwood PE, Galgano C, Golay A, Krejci I. Cytotoxicity and sealing properties of four classes of endodontic sealers evaluated by succinic dehydrogenase activity and confocal laser scanning microscopy. Eur J Oral Sci 2004;112:182-187.

20. Ciapetti G, Cenni E, Pratelli L, Pizzoferrato A. In vitro evaluation of cell/ biomaterial interaction by MTT assay. Biomaterials 1993;14:359-364.

21. Pinna L, Brackett MG, Lockwood PE, Huffman BP, Mai S, Cotti E, et al.. In vitro cytotoxicity evaluation of a self-adhesive, methacrylate resinbased root canal sealer. J Endod 2008;34:1085-1088.

22. Lodiene $G$, Morisbak E, Bruzell E, Ørstavik D. Toxicity evaluation of root canal sealers in vitro. Int Endod J 2008;41:72-77.

23. Huang FM, Chou MY, Chang YC. Induction of cyclooxygenase-2 mRNA and protein expression by epoxy resin and zinc oxide-eugenol based root canal sealers in human osteoblastic cells. Biomaterials 2003;24:1869-1875.

24. Huang TH, Ding SJ, Hsu TZ, Lee ZD, Kao CT. Root canal sealers induce cytotoxicity and necrosis. J Mater Sci Mater Med 2004;15:767-771.

25. Oztan MD, Yilmaz S, Kalayci A, Zaimoğlu L. A comparison of the in vitro cytotoxicity of two root canal sealers. J Oral Rehabil 2003;30:426-429.

Received October 31, 2012 Accepted December 5, 2012 